\title{
BRIDGING THE GAPS IN TREE-RING RECORDS: CREATING A HIGH-RESOLUTION DENDROCHRONOLOGICAL NETWORK FOR SOUTHEASTERN EUROPE
}

\author{
TOMASZ WAŻNY ${ }^{1,2}$, BRITA LORENTZEN ${ }^{3}$, NESIBE KÖSE ${ }^{4}$ ÜNAL AKKEMIK ${ }^{4}$, YURIJ BOLTRYK $^{5}$, TUNCAY GÜNER ${ }^{4}$, JOSEF KYNCL $^{6}$, \\ TOMAS̆ KYNCL ${ }^{6}$, CONSTANTIN NECHITA ${ }^{7}$, SEVERIN SAGAYDAK ${ }^{5}$, and JENI KAMENOVA VASILEVA ${ }^{8}$
}

${ }^{1}$ Laboratory of Tree-Ring Research, University of Arizona, 1215 E. Lowell Street, Tucson, AZ 85721, USA. Corresponding author: twazny@email.arizona.edu.

${ }^{2}$ Institute for the Study, Conservation and Restoration of Cultural Heritage, Nicolaus Copernicus University, ul. Sienkiewicza 30/32, 87-100 Toruń, Poland.

${ }^{3}$ Cornell Tree-Ring Laboratory, Cornell University, B-48 Goldwin Smith Hall, Ithaca, NY 14853, USA.

${ }^{4}$ Faculty of Forestry, Istanbul University, 34473 Bahçeköy, Istanbul, Turkey.

${ }^{5}$ Institute of Archaeology, National Academy of Sciences of Ukraine, Pr. Geroyiw Stalingrada 12, 04210 Kiev, Ukraine.

${ }^{6}$ DendroLab Brno, Eliasova 37, CZ-61600, Brno, Czech Republic.

${ }^{7}$ Forest Research and Management Institute, Campulung Moldovenesc, Calea Bucovinei 73bis, RO 725100, Romania.

${ }^{8}$ Department of Archaeology, Sofia University, Tsar Osvoboditel 15, 1000 Sofia, Bulgaria.

\begin{abstract}
Dendrochronological research in North-Central Europe and the East Mediterranean has produced networks of long regional oak (Quercus sp.) reference chronologies that have been instrumental in dating, provenancing, and paleoclimate research applications. However, until now these two important tree-ring networks have not been successfully linked. Oak forests and historical/archaeological sites in southeastern Europe provide the key for linking the North-Central European and East Mediterranean tree-ring networks, but previous dendrochronological research in this region has been largely absent. This article presents the initial results of a project, in which we have built oak tree-ring chronologies from forest sites and historical/archaeological sites along a north-south transect between Poland and northwestern Turkey, with the aim of linking the North-Central European and East Mediterranean tree-ring networks and creating a new pan-European oak data set for dendrochronological dating and paleoclimatic reconstruction. Correlation among tree-ring chronologies and the spatial distribution of their teleconnections are evaluated. The southeastern European chronologies provide a solid bridge between both major European dendrochronological networks. The results indicate that a dense network of chronologies is the key for bridging spatial and temporal gaps in tree-ring records. Dendrochronological sampling should be intensively continued in southeastern Europe because resources for building long oak chronologies in the region are rapidly disappearing.
\end{abstract}

Keywords: dendrochronology, Quercus sp., teleconnection, southeastern Europe, tree rings.

\section{INTRODUCTION}

Oak (Quercus sp.) has been the most important genus in the development of long tree-ring chronologies in both North-Central Europe and the East Mediterranean. Deciduous oak trees grow under a wide variety of ecological conditions throughout Europe from Turkey and Greece to southern Sweden and the Norwegian coast (Ducousso and Bordacs 2004). Strong teleconnections have been observed among oak chronologies from forest sites across North-Central Europe (Baillie 1983; Pilcher et al. 1984; Ważny and Eckstein 1991; Haneca et al. 2005, 2009; Kolar et al. 2012); moreover, there are generally strong heteroconnections among different oak species (Ufnalski 2006; Cedro 2007). Similarly strong teleconnections and heteroconnections have been observed in oak chronologies built from sites in the Aegean and East Mediterranean (Kuniholm and Striker 1987; Hughes et al. 2001; Griggs et al. 2007, 2009).

Oak wood is durable and resistant to degradation (Meiggs 1982; Haneca et al. 2009). These properties have contributed to the ubiquity of oak wood in historical and archaeological sites throughout Europe and the Mediterranean, allowing the extension of oak tree-ring chronologies far beyond the dates of the oldest oak trees in these regions (Haneca et al. 2005, 2009; Ważny 2009).

The North-Central European (NCE) oak tree-ring network has been built as the result of intensive work performed in a vast area from Ireland in the west (Baillie 1982) through the Alps and the Alpine foothills (Schweingruber and Ruoff 1979; Billamboz 2003), the Netherlands (Jansma 1995), NW Germany (Eckstein et al. 1979), and W Germany (Hollstein 1980) to Estonia (Läänelaid et al. 2008; Sohar et al. 2014) in the east. This work has resulted in the development of the longest continuous oak tree-ring chronology in the world, which spans the last 10,489 years (Friedrich et al. 2004). This series has been extended by overlapping pine chronologies (from the time when central Europe was still too cold for oak growth), so that for the NCE tree-ring network, there is a continuous tree-ring sequence spanning approximately 12,000 years, from the Younger Dryas until today (Schaub et al. 2008). 
In 1973, Peter I. Kuniholm launched the Aegean Dendrochronology Project, and began building tree-ring chronologies in Turkey, later expanding his research to sites in Greece, the Balkans, and Italy. The results of this work include a continuous tree-ring network for the East Mediterranean (hereafter EM) region comprised of oak sampled from forests and dendrochronologically dated historical and archaeological material that extends reliably back to AD 1089 from the present (Kuniholm and Striker 1987; Kuniholm 2000; Griggs et al. 2007, 2009; Pearson et al. 2012). Recent dendrochronological research on oaks from the Yenikap1 excavations in Istanbul, Turkey, may extend this chronology back to at least the 4th century BC (Pearson et al. 2012). Additional floating tree-ring chronologies built from oak and other species span much of the period between today and $7000 \mathrm{BC}$ and may extend tree-ring chronologies in the EM even further back in time (Kuniholm and Striker 1987; Kuniholm 1996).

The development of long oak tree-ring chronologies for both the NCE and EM regions has provided data for paleoclimatic reconstructions (e.g. Griggs et al. 2007; Büntgen et al. 2011) and absolute dates for numerous historical and archaeological sites (Kuniholm and Striker 1987; Kuniholm 2000; Haneca et al. 2009). Dendrochronological analysis of NCE and EM oaks imported through long-distance trade has also provided dates for sites outside of these regions in the southern Levant (Bernabei and Bontadi 2012; Lorentzen 2014) and the Red Sea (Müller and Heußner 2012).

However, despite strong teleconnections and heteroconnections among oaks within the NCE and EM regions and success in using these chronologies for dendrochronological dating and other research applications, previous research efforts have been unable to link these two large chronological networks with one another. Finding such a link would verify the placement of the EM chronologies covering a significant part of the 1 st and 2nd millennium $\mathrm{AD}$ and could provide absolute dating of the now floating Aegean BC chronology. The geographic distance between sites sampled in the NCE and EM networks is less than $200 \mathrm{~km}$ across the Alps, and yet no dendrochronological linkages between the two networks could be found. After preliminary investigations of these two tree-ring networks, it was therefore concluded that in North-Central Europe and southeastern Europe/northern Anatolia there are two separate dendrochronological "zones," with the Alps creating a distinct boundary (Čufar et al. 2008; Ważny 2009).

After unsuccessful efforts to link the NCE and EM tree-ring networks across the Alps, we decided to investigate building a dendrochronological "bridge" through southeastern Europe. Other than a few published dendroclimatological studies on non-oak species (e.g. Popa and Kern 2008; Panayotov et al. 2010; Trouet et al. 2012), there are few dendrochronological data sets from the area between Poland - the home of the first author (where a dense network of dendrochronological data is available, e.g. Ważny 1990; Krąpiec 1998; Haneca et al. 2005; Ufnalski 2006; Cedro 2007)and "Kuniholm's empire" in the northeastern Mediterranean.
Short feasibility trips to Romania, Bulgaria, Ukraine, and Slovakia confirmed the potential of the region to link the NCE and EM tree-ring records, both in terms of available timber resources and tree-ring teleconnections. The distance between the NCE and EM tree-ring networks is much larger (ca. 700-900 km) in southeastern Europe than across the Alps. Yet, preliminary results from this work suggested that tree-ring chronologies from the region along the Carpathian Mountains successfully bridge the NCE and EM tree-ring networks (Ważny 2009).

Southeastern Europe also served as an important source of timber both within the region and beyond. For example, forests growing on the flooded area near Satu Mare in Romania, close to the Hungarian border, delivered timber to Venice and the US about 150 years ago, according to information from the Forest Service in Satu Mare. The Danube, the second largest river in Europe, and its tributaries provided excellent opportunities for long-distance trade and transport both within Europe and even to the EM. For example, Pearson et al. (2012) provided the first dendrochronological evidence of the Danube Basin as a source of timber for Justinianic Constantinople. Dendroprovenancing methods developed for NCE (Eckstein et al. 1986; Bonde et al. 1997) are applicable also to southeast Europe (hereafter SE Euope).

Additionally, fossil pollen data indicate that the southern Balkan Peninsula and the western Black Sea coast served as refugia for deciduous oak during the last glacial period (ca. pre-10 ka BP) (Brewer et al. 2002). Consequently, paleoenvironmental sites in southeastern Europe may produce oak tree-ring data from time periods preceding those of the oldest oak tree-ring data from either the EM or northern Europe and therefore the longest oak treering chronologies in Europe.

Given the great potential importance of southeastern Europe for dendrochronological research, we decided to sample modern and historical/archaeological sites and build a tree-ring data set along an approximately $1300-\mathrm{km}$ transect from southeastern Poland in the NCE network to northwestern Turkey in the EM tree-ring network, bridging both sides of the Carpathian Mountains. The objectives for this project consisted of the following:

- to link the East Mediterranean chronologies to the long, absolutely dated North-Central European master chronologies;

- to develop tree-ring data sets as a tool for dating historical objects and for determining the origin of these materials (i.e. dendroprovenancing);

- to delineate geographic areas along this transect in which there are common tree-ring patterns (i.e. areas with the same "dendrochronological signal").

\section{MATERIAL AND METHODS}

The study area for this project includes forest, historical, and archaeological sites in seven countries. In total, 480 samples from 
26 sites were collected along a transect extending from Poland to northwestern Turkey. The location of the sites and of preexisting oak reference chronologies used in this study are shown in Figure 1. Five oak species [Quercus robur L., Quercus petraea (Mattuschka) Liebl., Quercus cerris L., Quercus frainetto Ten., and Quercus pubescens Willd.] were included in this project. The location and description of each site and oak species sampled is given in Table 1.

\section{Forest Sampling Locations and Methods}

Sampling of living trees targeted oaks growing primarily in protected nature reserves (in which there had been theoretically minimal anthropogenic disturbance), supplemented by groups of old trees surviving in managed forests. Cores were taken from each tree with a Haglof increment borer at breast height $(1.3 \mathrm{~m})$, and in some cases sections were cut from felled trees with a chainsaw.

The ecological and geographic diversity of the study area is enormous, ranging from the Black Sea coast and including both the European and Asian sides of northwestern Turkey, to the Danube and Dniester River valleys, and from the Carpathian Mountains to the Middle European Plain. Oaks grow in environments including open park forests, mixed broadleaf forests, monotypic managed forests, humid broadleaf forests, and even subhumid tropical broadleaf forests.

Particularly unique ecological areas sampled include forest sites in Romania (Figure 1, sites \#9-15) and in the Strandja Mountains on the SE Bulgarian-NW Turkish border (Figure 1, sites \#22 and \#24). Romania is a central and critical transition zone in our study area, because it is the location where the Euroasiatic deciduous forest, Atlantic domain (dominated by deciduous broad-leaved trees), and Mediterranean forest domain converge (Ozenda 1994; Bodnariuc et al. 2002). The Strandja Mountains contain humid continental to subhumid tropical relict broadleaf forests containing high biodiversity and species richness. The area's unique ecology is because of its location at a biogeographic crossroad between Europe and Asia, and because Strandja was a refugium for broadleaf forests (including oak) during the Late Glacial Period. Oaks from both sides of the mountains - the Strandja Nature Park (Figure 1, site \#22) in Bulgaria along the northern mountain slopes, and managed forests at Soğuksu (Figure 1, site \#24) in the Demirköy district in Turkey on the southern slopes-were sampled and compared.

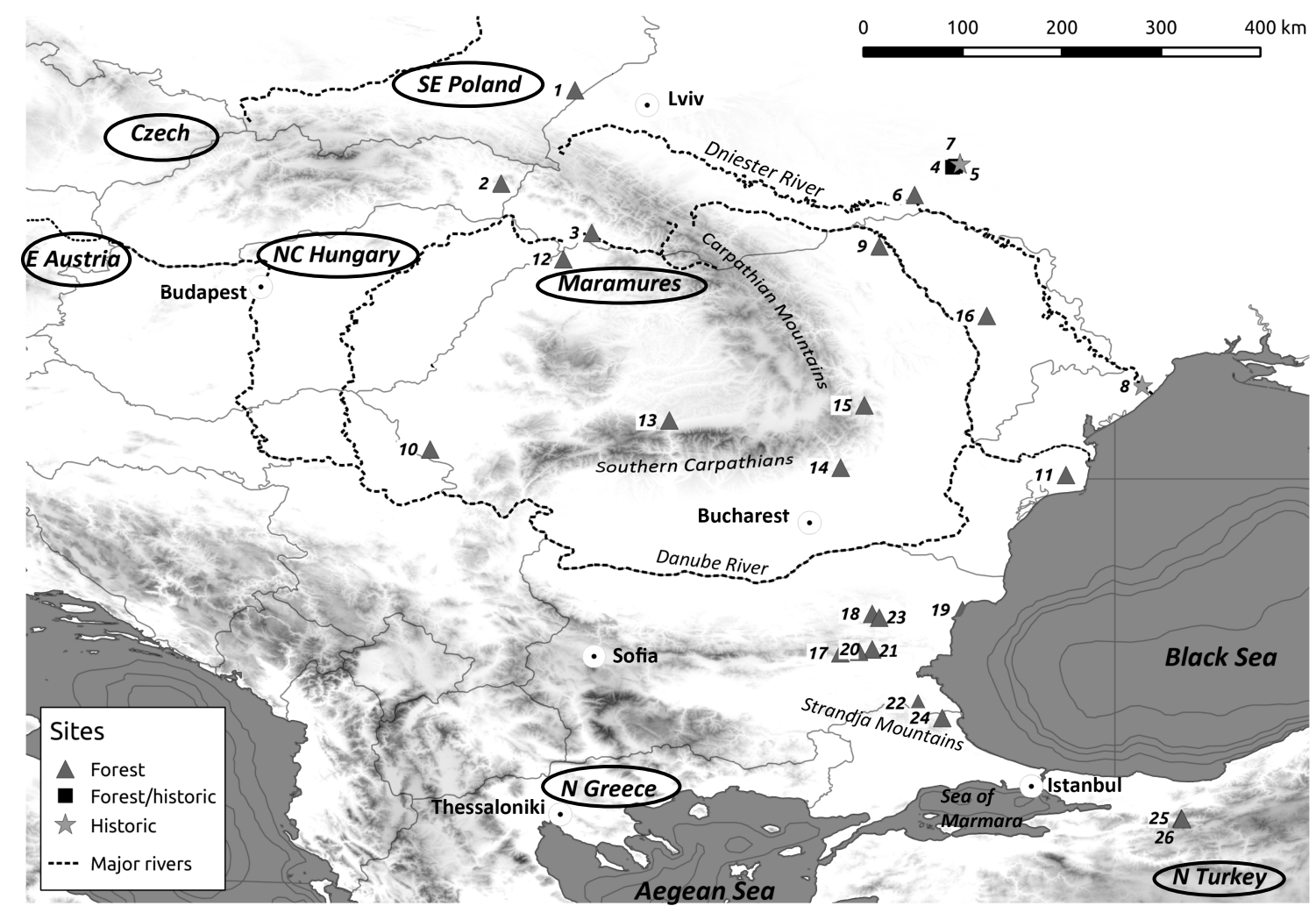

Figure 1. Map of SE Europe indicating the sampling locations of the forest sites (gray triangles), historical buildings (gray stars), both forests and historical buildings (black squares), and pre-existing oak reference chronologies (black ovals). The site chronologies corresponding to the site numbers on the map are listed in Table 1. 
Table 1. Location and description of sites sampled in this study.

\begin{tabular}{|c|c|c|c|c|c|c|c|c|}
\hline No. & Country & Site & $\begin{array}{l}\text { Longitude } \\
\text { (E) }\end{array}$ & $\begin{array}{l}\text { Latitude } \\
(\mathrm{N})\end{array}$ & $\begin{array}{l}\text { Altitude } \\
\text { (m asl) }\end{array}$ & Type of site & $\begin{array}{l}\text { No. of trees/ } \\
\text { samples collected }\end{array}$ & Species \\
\hline 1 & Poland & Kosobudy & 23.06 & 50.04 & $280-300$ & forest/publ. data ${ }^{1}$ & 20 & Q. robur $/ Q$ petraea \\
\hline 2 & Slovakia & Jovsianska Hrabina & 22.11 & 48.83 & $180-200$ & forest & 16 & Q. robur \\
\hline 3 & Ukraine & Khust & 23.27 & 48.19 & $250-270$ & forest & 18 & Q. robur \\
\hline 4 & Ukraine & Czerniatyn & 27.91 & 49.04 & $320-325$ & forest + historical & $16+11$ & Q. robur \\
\hline 5 & Ukraine & Severinovka & 27.90 & 49.06 & $280-310$ & forest+historical & $16+27$ & Q. robur \\
\hline 6 & Ukraine & Naddnistrie & 27.42 & 48.68 & 280 & forest & 17 & Q. robur \\
\hline 7 & Ukraine & Mezhiriv & 28.01 & 49.08 & 266 & historical & 11 & Quercus sp. \\
\hline 8 & Ukraine & Akkerman & 30.35 & 46.20 & ca. 10 & historical & 10 & Quercus sp. \\
\hline 9 & Romania & Avrămeni & 26.97 & 48.01 & 199 & forest & 15 & Q. robur \\
\hline 10 & Romania & Banloc & 21.20 & 45.38 & 93 & forest & 17 & Q. robur \\
\hline 11 & Romania & Caraorman & 29.37 & 45.05 & 3 & forest & 18 & Q. robur \\
\hline 12 & Romania & Satu Mare & 22.91 & 47.85 & 127 & forest & 34 & Q. robur \\
\hline 13 & Romania & Sibiu & 24.27 & 45.76 & 440 & forest & 15 & Q. robur \\
\hline 14 & Romania & Tisau & 26.47 & 45.15 & 270 & forest & 35 & Q. petraea \\
\hline 15 & Romania & Vizantea & 26.78 & 45.95 & 628 & forest & 30 & Q. petraea \\
\hline 16 & Moldova & Lozova & 28.35 & 47.11 & 237 & forest & 16 & Q. robur \\
\hline 17 & Bulgaria & Sinije Kamni & 26.47 & 42.74 & $780-830$ & forest & 11 & Q. cerris \\
\hline 18 & Bulgaria & Szumensko Plateau & 26.88 & 43.25 & $480-490$ & forest & 24 & Q. petraea/Q. cerris \\
\hline 19 & Bulgaria & Zlatni Piasci & 28.04 & 43.30 & $100-130$ & forest & 20 & Q. cerris \\
\hline 20 & Bulgaria & Lazarevo & 26.88 & 42.79 & $280-290$ & forest & 16 & Q. cerris $/ Q$. pubescens \\
\hline 21 & Bulgaria & Czubra & 26.71 & 42.76 & 210 & forest & 16 & Q. cerris \\
\hline 22 & Bulgaria & Zvezdec & 27.47 & 42.09 & $300-340$ & forest & 21 & Q. frainetto/Q. cerris \\
\hline 23 & Bulgaria & Marash & 26.97 & 43.20 & 95 & forest & 2 & Q. robur \\
\hline 24 & Turkey & Soğuksu & 27.78 & 41.90 & $360-370$ & forest & 20 & $Q$. petraea/Q. frainetto \\
\hline 25 & Turkey & Sakir & 30.85 & 40.60 & 770 & forest & 20 & Q. cerris $/ Q$. petraea \\
\hline 26 & Turkey & Güzlek & 30.86 & 40.59 & 610 & forest & 8 & Q. cerris \\
\hline
\end{tabular}

1. Ważny (1990).

\section{Historical and Archaeological Sampling Locations and} Methods

In Eastern Europe, it is extremely difficult to find oak trees over 200 years old. Therefore, to extend our recent chronologies further back in time, we also collected materials from historical and archaeological sites (Figure 1; Table 1). Historical and archaeological material were sampled either by cutting cross-sections of the wood or by obtaining cores of the material with a dry-wood borer.

In Ukraine, it was possible to obtain an especially rich collection of historical timber in Podolia. This area is located near the Dniester River, which flows from the Polish-Ukrainian border to the Black Sea and historically served as a conduit for transporting timbers used to build a series of Moldavian-Ottoman fortresses (like the Akkerman Fortress in Bilhorod Dnistrovskyi; Figure 1, site \#8). In Podolia, it was possible to find 18th-19th century buildings adjacent to contemporary forest stands containing old trees. Buildings sampled in this area include a ruined sugar factory (built in 1873) and nearby forest park in Severinovka (Fig- ure 1, site \#5); the remains of the Church of the Assumption of the Virgin Mary (built in 1794) in Mezhiriv (Figure 1, site \#7); and the roof of the palace in Czerniatyn, which was the estate of the Vitoslavskyi-Lvov family from the 17th-19th centuries, as well as modern oaks from a nearby park that is likely a remnant of an old forest (Figure 1, site \#4).

\section{Laboratory and Analysis Methods}

Sample preparation, crossdating, and chronology building were carried out using classical dendrochronological methods (e.g. Baillie 1982; Schweingruber 1988; Hillam 1998). All ring widths were measured to the nearest $0.01 \mathrm{~mm}$ using a stereomicroscope, traveling stage, and the TSAPWin (Rinn 2005) and CORINA (Harris et al. 2008) dendrochronological analysis programs. Samples from the same forest site or building structure were crossdated with one another and synchronized to build composite site chronologies. Historical site chronologies were crossdated against local chronologies developed from living trees and absolutely dated reference chronologies from Slovakia developed by T. Kyncl (unpublished). 
Crossdating was evaluated using multiple statistical parameters-namely, $t$-values (Baille and Pilcher 1973), percent parallel variation (Gleichläufigkeit) (Eckstein and Bauch 1969), and the TSAP Crossdating Index - using the software TSAPWin (Rinn 2005), CORINA (Harris et al. 2008), and DENDRO for Windows (Tyers 2004). Crossdating was verified by visual inspection and by the COFECHA software (Holmes 1983). In cases when various oak species were sampled from the same forest site, separate chronologies for each sampled species were built and compared. However, because visual and statistical similarities between oak species at the same site were so strong, the tree-ring series of different oak species were pooled together into composite oak chronologies for each site. Tables 2 and 3 list the chronologies developed from the study area and regional reference chronologies analyzed.

Intersite correlation of oak chronologies in the study area (and thus the strength of the SE European tree-ring signal) was evaluated by examining the $t$-values obtained between different pairs of chronologies (Baillie 1982; Baillie and Pilcher 1973). In this study, $t$-values $>4.0$ indicate significant correlation between chronologies.

Applying different indexing and autoregression models to standardize tree-ring curves can greatly affect the $t$-values calculated between two chronologies, particularly between chronologies with moderate to poor correlation (Wigley et al. 1987). Tests carried out by Sander and Levanič (1996) further demonstrate that different dendrochronological software packages may produce different $t$-values, even when similar or even the same formulas are used in their calculation. Therefore, we used $t$-values calculated in TSAP (Rinn 2005) according to the Hollstein algorithm $\left(t_{\mathrm{H}}\right)$ (Hollstein 1980) to keep the results consistent. Calculated $t_{\mathrm{H}}$-values between chronologies were cross-checked with their corresponding BailliePilcher $t$-values $\left(t_{\mathrm{BP}}\right)$ (Baillie and Pilcher 1973) in TSAPWin and their visual fit to assess overall correlation. Additional transformation and standardization of the tree-ring data beyond that applied in the Hollstein and Baillie-Pilcher algorithms was not performed, as our raw tree-ring data did not exhibit particularly strong undesirable trends caused by age or stand dynamics.

Table 2. Oak chronologies developed for the project. Site \#1 is already published (Ważny 1990).

\begin{tabular}{cllllll}
\hline Site no. & Country & Chronology & No. of series & Length (years) & Date begin & Date end \\
\hline 1 & Poland & Kosobudy & 20 & 207 & 1782 & 1988 \\
2 & Slovakia & Jovsianska Hrabina & 15 & 110 & 1902 & 2011 \\
3 & Ukraine & Khust & 18 & 142 & 1867 & 2008 \\
4 & Ukraine & Czerniatyn forest & 12 & 197 & 1813 & 2009 \\
4 & Ukraine & Czerniatyn palace & 6 & 160 & 1677 & 1836 \\
5 & Ukraine & Severinovka forest & 11 & 217 & 1793 & 2009 \\
5 & Ukraine & Severinovka factory & 13 & 199 & 1643 & 1841 \\
6 & Ukraine & Naddinstrie & 14 & 100 & 1910 & 2009 \\
7 & Ukraine & Mezhiriv church & 6 & 118 & 1676 & 1793 \\
8 & Ukraine & Akkerman fortress & 21 & 116 & 1677 & 1792 \\
9 & Romania & Avrămeni & 15 & 141 & 1867 & 2007 \\
10 & Romania & Banloc & 15 & 156 & 1852 & 2007 \\
11 & Romania & Caraorman & 6 & 168 & 1839 & 2006 \\
12 & Romania & Satu Mare & 32 & 129 & 1882 & 2010 \\
13 & Romania & Sibiu & 13 & 198 & 1810 & 2007 \\
14 & Romania & Tisau & 35 & 167 & 1844 & 2010 \\
15 & Romania & Vizantea & 28 & 173 & 1838 & 2010 \\
16 & Moldova & Lozova & 11 & 136 & 1871 & 2006 \\
17 & Bulgaria & Sinije Kamni & 11 & 95 & 1915 & 2009 \\
18 & Bulgaria & Szumensko Plateau & 24 & 115 & 1895 & 2009 \\
19 & Bulgaria & Zlatni Piasci & 20 & 103 & 1907 & 2009 \\
20 & Bulgaria & Lazarevo & 16 & 112 & 1898 & 2009 \\
21 & Bulgaria & Czubra & 16 & 202 & 1808 & 2009 \\
22 & Bulgaria & Zvezdec & 21 & 223 & 1787 & 2009 \\
23 & Bulgaria & Marash & 20 & 217 & 1793 & 2009 \\
24 & Turkey & Soguksu & 146 & 1864 & 2009 \\
25 & Turkey & Sakir & 222 & 1788 & 2009 \\
\hline & & & & &
\end{tabular}


Table 3. List of reference oak chronologies.

\begin{tabular}{lccll}
\hline Chronology & Length & Date begin & Date end & Reference \\
\hline SE Poland & 895 & 1100 & 1994 & Krąpiec (1998) \\
Czech & 1655 & 352 & 2006 & Kolar et al. (2012) \\
E Austria & 833 & 1172 & 2003 & Grabner (unpublished) \\
N Central Hungary & 405 & 1590 & 2004 & Grynaeus (unpublished) \\
Maramures & 588 & 1406 & 1994 & Eggertson and Babos (2002) \\
N Greece & 794 & 1186 & 1979 & Kuniholm and Striker (1987) \\
N Turkey & 924 & 1081 & 2004 & Griggs et al. (2009) \\
\hline
\end{tabular}

\section{RESULTS}

\section{Regional Teleconnections among Site Chronologies}

The main goals of the project were to link the absolutely dated NCE and EM tree-ring networks for the period of the last several centuries and assess the common dendrochronological "signal" of trees growing in SE Europe. Figure 2 shows the site chronologies in the study area that have significant correlation with one another, which are linked with black lines.
As shown in Figure 2, the NCE oak chronologies in Poland, East Austria, and the Czech Republic have successfully been linked to the EM dendrochronological network of NW Turkey through the SE European dendrochronological "bridge." There are substantial long-distance east-west teleconnections in the study area across the Greater Hungarian Plain. The 600-year Maramures chronology (Eggertson and Babos 2002) has strong correlation $\left(t_{\mathrm{H}}=9.6\right)$ with Grabner et al.'s (unpublished data) E Austria reference chronology that is over $600 \mathrm{~km}$ distant. Such long-distance east-

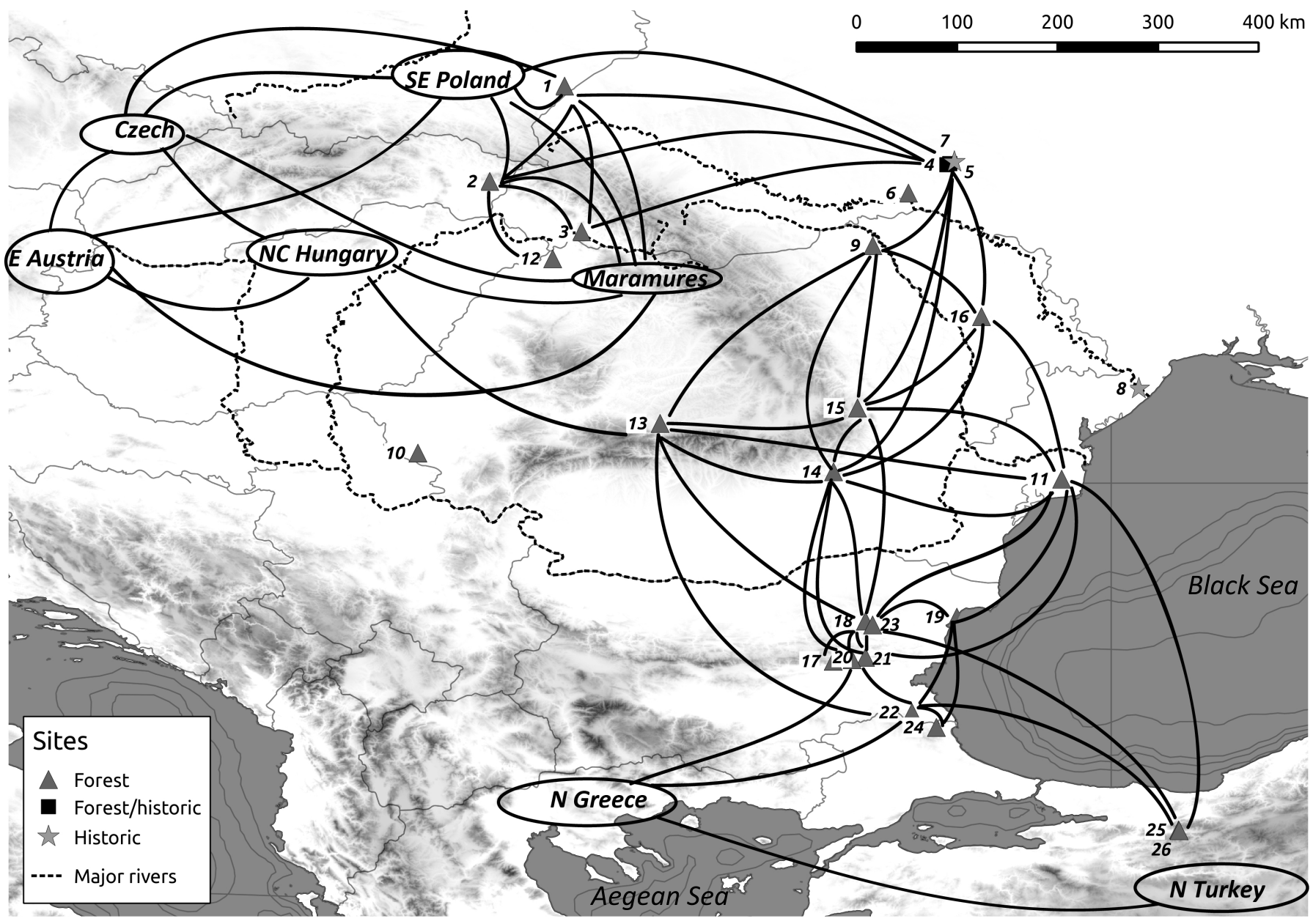

Figure 2. Map of SE Europe with lines indicating significant $(t \geq 4.0)$ correlation between pairs of oak chronologies. Site chronologies corresponding to the site numbers on the map are listed in Table 1. Ovals indicate regional reference chronologies. 
west teleconnections also exist among site chronologies for which the overlap is much shorter $(n<220)$. The Ukrainian chronologies from Czerniatyn (\#4) and Severinovka (\#5) have $t$-values of 6.3 and 7.0, respectively, against the SE Poland reference chronology (Krąpiec 1998), which is located approximately $500 \mathrm{~km}$ away. It should be noted that in northern Poland, Ważny and Eckstein (1991) previously observed high correlation between sites over distances of about $400 \mathrm{~km}$. They also noted that in some periods a common dendrochronological signal might exist far beyond this distance.

However, teleconnections obtained among individual site chronologies and their spatial distributions (shown in Figure 2, and in detail in Figures 3 and 4) do not entirely match our original hypothesis. We had expected primarily teleconnections running in a N-S direction in SE Europe, reflecting a common tree-ring signal in sites running parallel to the main chain of the Carpathians, and poor correlation between sites on the eastern and western sides of these mountains. There is indeed a distinct boundary between Maramures in northwest Romania (which clearly belongs to the NCE dendrochronological zone) and the neighboring regions of Bukovina (\#13) and Transylvania (\#9) only slightly further east in Romania (ca. 200 km). Additionally, the Maramures chronology does not have significant correlation with any sites located to its south, east, or northeast across the Carpathians. This general pattern likely results from the influence of the Carpathian Mountains, which restrict the influence of continental air masses from central Europe to western Romania, and the influence of Black Sea air masses to the country's east (Bojariu and Giorgi 2005). Yet, contrary to our expectations, we note strong correlation between Sibiu (Figure 2, site \#13), which is located in Bukovina west of the Carpathians, and forest sites on the eastern slopes of the Carpathians and in eastern Romania (e.g. Figure 2, sites \#9, 14, and 15). Furthermore, sites in Transylvania belong to the dendrochronological zone east of the Carpathians and do not exhibit strong teleconnections to the Great Hungarian Plain.

For some sites, a lack of significant teleconnections likely arises from local environmental conditions, disturbances, or anthropogenic influences dominating the tree-ring signal. For example, Satu Mare in NW Romania (\#12) is located in a flooded area, and its site chronology exhibits poor correlation even with nearby sites. Forest management and anthropogenic disturbance can reduce the strength of the dendrochronological signal significantly and consequently the value of sites for long-distance crossdating. For example, the forest site of Naddnistrie (\#6) in Ukraine shows only very low correlation with the sites of Czerniatyn (\#4) and Severinovka (\#5) despite a distance of less than $80 \mathrm{~km}$. The

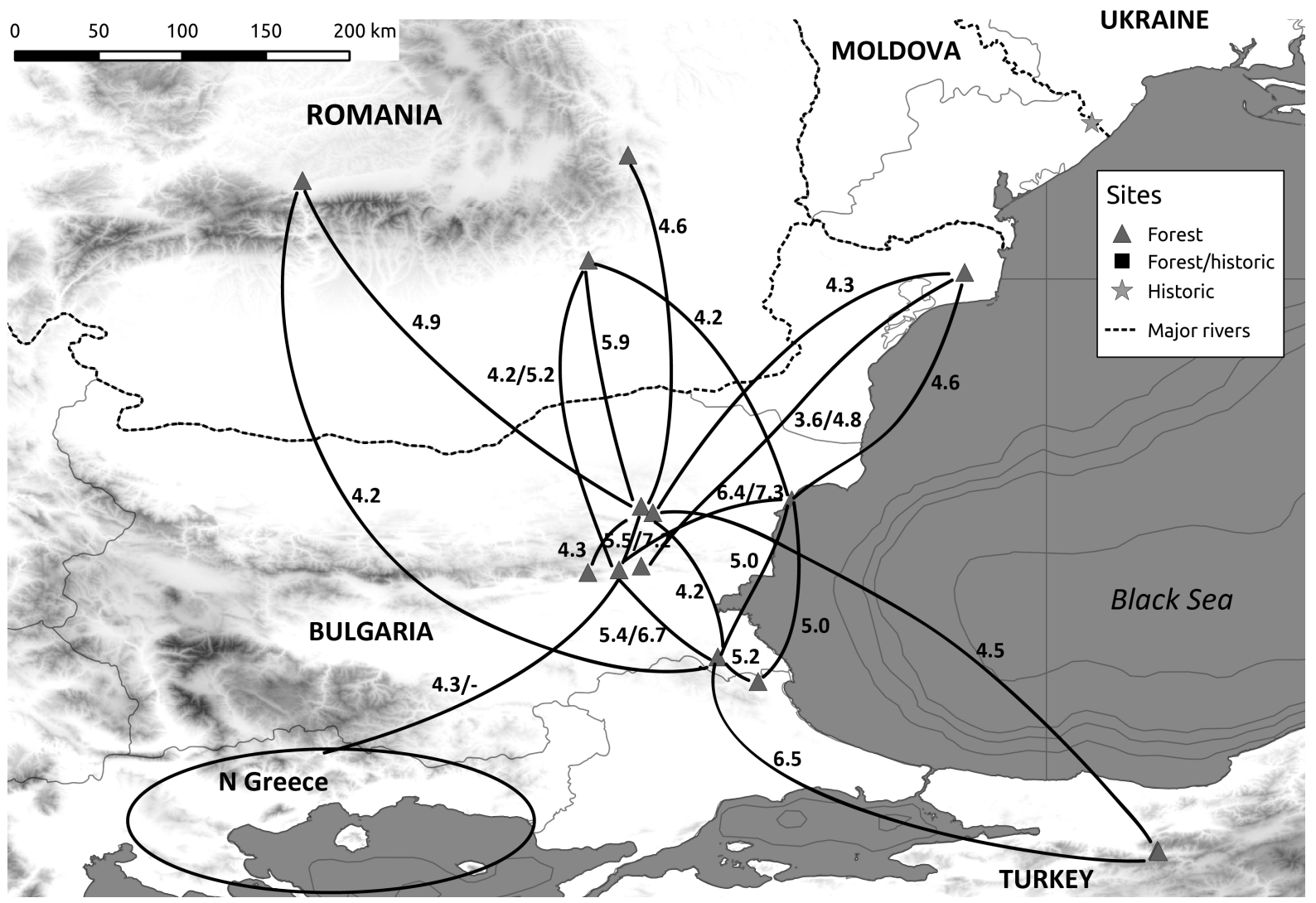

Figure 3. Location of and correlation among Bulgarian, Romanian, and Turkish oak forest chronologies. The N Greece reference chronology is indicated with an oval. $t$-values show the correlation strength between chronologies (connected with an arc) are displayed. All $t$-values shown here are calculated using the Hollstein algorithm $\left(t_{\mathrm{H}}\right)$. In a few cases where there is a large difference between $t_{\mathrm{H}}$-values and $t$-values calculated using the Baillie-Pilcher algorithm $\left(t_{\mathrm{BP}}\right)$, both $t_{\mathrm{H}}$ (listed first) and $t_{\mathrm{BP}}$ (listed second) statistics are given. 


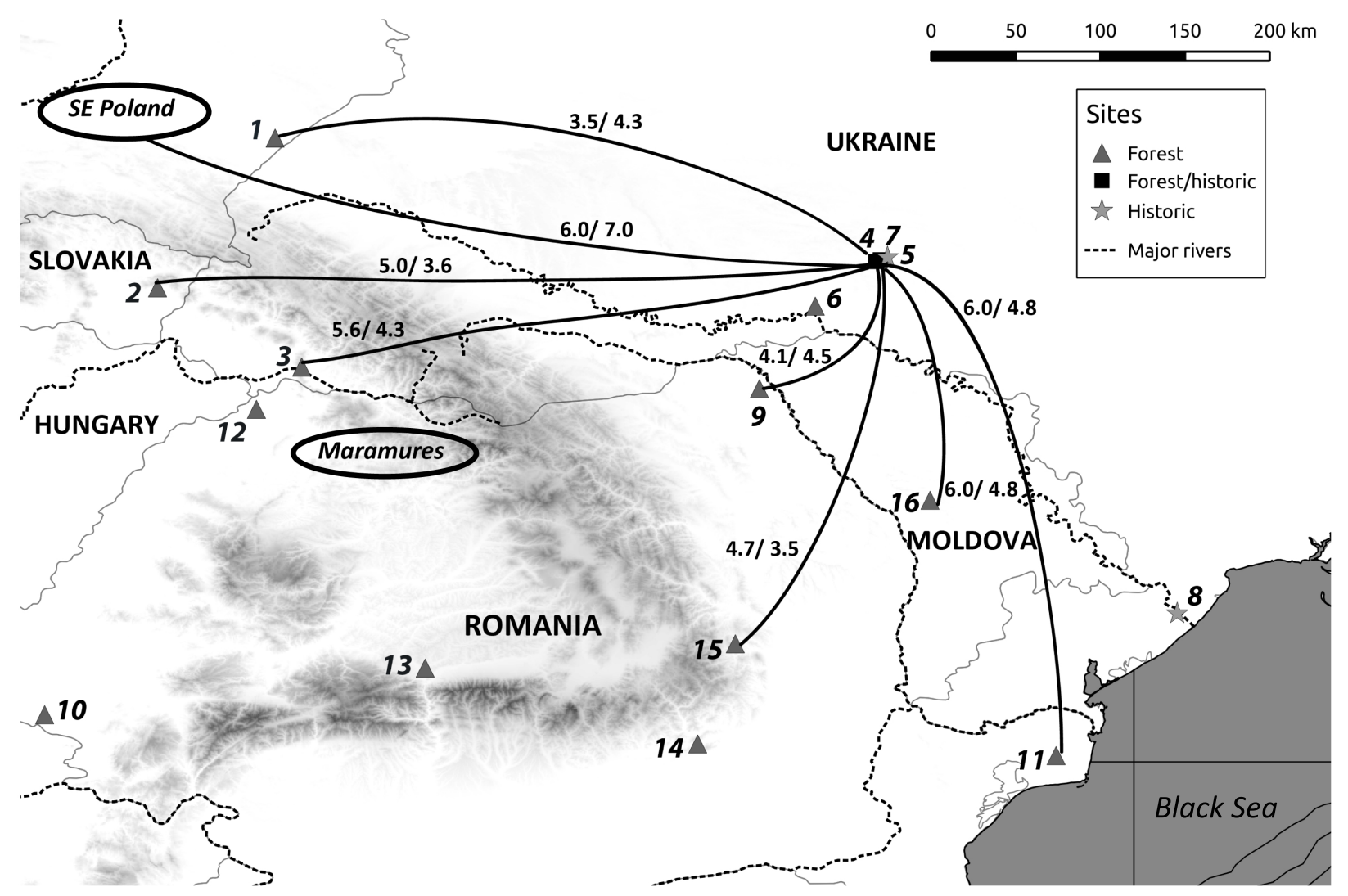

Figure 4. Historical and modern oak chronologies representing the region of Podolia in Ukraine. $t$-values show the significance of relationships between chronologies (connected with an arc). All $t$-values shown here are calculated using the Hollstein algorithm ( $t_{\mathrm{H}}$ listed first) and using the Baillie-Pilcher algorithm ( $t_{\mathrm{BP}}$ listed second). Ovals indicate regional reference chronologies. The site chronologies corresponding to the site numbers on the map (in bold italics) are listed in Table 1.

effects of forest management are also clear when we compare the teleconnections of two chronologies from forest sites in the Strandja Mountains on the western coast of the Black Sea. The site of Zvezdec (\#22), which is in a protected nature reserve natural forest in Bulgaria, has stronger correlation $\left(t_{\mathrm{H}}=6.5\right)$ with the unmanaged forest site of Sakir on the Asian side of Turkey (a distance of $\sim 300 \mathrm{~km}$ ) than with the managed forest site of Soğuksu $(\# 24)\left(t_{\mathrm{H}}=5.2\right)$, which is only $35 \mathrm{~km}$ away on the other side of the Strandja Mountains.

Both Kuniholm's (2000) and Griggs et al.'s (2007, 2009) Aegean oak master reference chronologies for north Greece and north Turkey show limited teleconnections with the SE European tree-ring network and consequently reduced usefulness for crossdating with SE European oak chronologies (Figure 3). The north Greece oak chronology has only moderate correlation $\left(t_{\mathrm{H}}=\right.$ 4.3) against two Bulgarian site chronologies, Lazarevo and Zvedec (\#20 and \#22, respectively), whereas the north Turkey oak reference chronology does not show significant correlation with any chronology except Sakir (\#25) in NW Turkey. In contrast, Sakir has significant correlation with two Bulgarian sites: Zvez$\operatorname{dec}\left(\# 22 ; t_{\mathrm{H}}=6.5\right)$ and Shumensko Plateau $\left(\# 18 ; t_{\mathrm{H}}=4.5\right)$. There is even a significant link $\left(t_{\mathrm{H}}=4.0\right)$ across the Black Sea between Sakir and Caraorman (\#11) in Romania. These results suggest that the north Turkey oak chronology—which comprises several site chronologies whose locations range from the European provinces of Turkey to Turkey's eastern Black Sea coast—should be divided into smaller, well-replicated units that better capture mesoscale to local variability in the dendrochronological record. Such "deconstruction" of the Aegean oak master chronologies will improve our ability to date wood from the SE European "transition zone" and improve the use of such chronologies in dendroprovenancing applications. This process of "dismantling" large-scale oak reference chronologies into robust, smaller-scale regional treering chronologies has already begun elsewhere in western Europe with chronologies such as Eckstein's Schleswig-Hollstein oak chronology (Eckstein and Wrobel 2007).

\section{Dating and Provenancing Historical and Archaeological Sites}

Historical timbers from Severinovka (\#5), Czerniatyn (\#4), and Mezhiriv (\#7) extended our Ukrainian oak chronologies by 150 years, so that a regional chronology for Podolia now extends back to AD 1643 from the present. The successful dating of these timbers and developed chronologies also solved the problem of dating the Akkerman-Late chronology developed for the Late Ottoman structures built during the modernization of the Akkerman Fortress in Bilhorod Dnistrovski, $15 \mathrm{~km}$ north of the Black Sea 
coast (Bilyayeva et al. 2010). This chronology had remained undated even after three sampling campaigns. The Akkerman-Late chronology crossdates with the newly developed Severinovka Sugar Factory chronology with a high $t_{\mathrm{H}}$-value of 8.0, indicating that the timbers were imported from Podolia. This chronology covers the period of AD 1677-1792.

Not all attempts to sample historical and archaeological material in the study area were successful. We attempted to sample from the Tombul Mosque (the Sherif Halil Pasha Mosque, ca. 1740-1744), which is the largest mosque in Bulgaria and one of the largest mosques in the Balkans. However, we discovered that the mosque's original wooden construction was replaced during restoration in 2010, and the timbers thrown out. Only three original timbers, probably originating from the cupola construction, were found in the mosque courtyard below a pile of lead waste from the roof cladding. This mosque is one of many examples of fast-disappearing historical timber resources for dendrochronological research in the Balkans.

\section{DISCUSSION}

\section{Oak Teleconnections and Atmospheric Circulation Patterns}

Oaks are present throughout almost the entire length of the transect in our study area, except at higher elevations in the mountains. We sampled and analyzed oaks growing on both sides of the Carpathian Arc through the following three phytogeographical provinces of the Boreal Subkingdom: Central-European Lowland-Upland Province, Pontic-Pannonian Province, and Illyrian Province. The southernmost part of our transect extends into the Mediterranean Kingdom (classification based on Medwecka-Kornaś 1972).

The spatial distribution of teleconnections in our study area's tree-ring records most likely has a climatological basis, because the teleconnections generally follow the paths of large-scale atmospheric circulation patterns. Previous studies indicate that precipitation, particularly during spring and summer months, has an important impact on radial growth in oaks (e.g. Ważny and Eckstein 1991; Akkemik et al. 2005; Cedro 2007; Griggs et al. 2007). Cyclone trajectory and frequency are highly correlated with the spatial and temporal variability of precipitation in this region and can therefore impact site and regional tree-ring signals (Karaca et al. 2000; Bielec-Bakowska 2010; Kaznacheeva and Shuvalov 2012).

The northernmost sites in the study area are strongly influenced by cyclones originating over the North Atlantic. These cyclones travel from west to east across either Iceland or the British Isles and through northern Europe. SE Poland and central Europe have a continental climate that is also strongly influenced by cyclones that form in the Gulf of Genoa in the central Mediterranean and then travel to the northeast through central Europe (BielecBakowska 2010). This common climatic influence may explain the long-distance teleconnections running from the west in Austria and the Czech Republic through to central Hungary, Maramures, and western Ukraine.
Precipitation in northwest Turkey and north Greece, at the southernmost point in our transect, is primarily influenced by cyclones of Mediterranean origin. These cyclones, originating in the western or central Mediterranean, move to the northeast toward the Black Sea and affect the Balkans (including sites in the Strandja Mountains), areas around the Sea of Maramara, and central-eastern Black Sea region. Northwest Turkey, Greece, and southeastern Bulgaria may also be influenced by cyclones originating in the Balkans, which move to the southeast and over the Sea of Marmara and Black Sea coast (Karaca et al. 2000).

Romania - the critical "bridge" linking the NCE and EM dendrochronological zones in our study area-is also located at an important climatic junction of multiple atmospheric circulation patterns. Precipitation in northwest Romania, including the Maramures area, is influenced by the cyclone track that also influences much of central Europe and southeast Poland (Bielec-Bakowska 2010). Southwestern and southern Romania receive Mediterranean cyclones originating in either the Adriatic or north Aegean Seas, which also pass through the Balkans (including the southern part of our study area) (Bojariu and Giorgi 2005; Kaznacheeva and Shuvalov 2012). Mediterranean cyclones passing through the Balkans and northwest Turkey may also be intensified by the Black Sea and follow a trajectory along the sea's western coast (Bojariu and Giorgi 2005). The trajectory of these types of cyclones largely follows the north-south teleconnections running from the Strandja Mountains through eastern Romania and Moldova to southern Ukraine.

The Carpathian Mountains and other local topography heavily restrict movements of continental and Mediterranean air masses and modulate the effects of atmospheric circulation patterns on both precipitation and temperature in our study area (Bojariu and Giorgi 2005). The limited tree-ring teleconnections across the Carpathian Arc (particularly between the Maramures chronology and other chronologies to the south and east of the Carpathians) in the study area indicate the critical role that these mountains have on the region's climate and (consequently) tree-ring signals. Nevertheless, as noted previously, significant teleconnections exist between the Sibiu site chronology (site \#13) and other sites across the southern and eastern Carpathian chains. This suggests that Sibiu may be part of a unique microclimate that is influenced by both central European and Black Sea/Mediterranean air masses. The forthcoming addition of several new oak chronologies from Romania (Nechita 2013), particularly from the Transylvanian Plateau, may further illuminate the extent of, and bioclimatic conditions leading to, such trans-Carpathian teleconnections.

\section{Oak Teleconnections and Post-Glacial Migration Routes}

The spatial distribution of teleconnections among the tree-ring site chronologies also corresponds to the pathways along which oaks likely migrated from their primary refugia in SE Europe to northern Europe at the beginning of the Holocene. Palynological and DNA evidence indicate that during the last glaciation, de- 
ciduous oak taxa survived in three primary refugia in southern Europe: southern Spain, southern Italy, and the southern Balkans (Brewer et al. 2002; Petit et al. 2002). Over 71\% of oaks examined in Poland (the northernmost end of the transect in our study area) belong to the Balkan haplotype (Dering et al. 2008), indicating that these oaks originated from the Balkan refugia.

The most probable locations of the Balkan glacial refugia are in western Greece in the region of Ioannina and on the western coast of the Black Sea (Brewer et al. 2002). Oak refugia were located usually in mid-altitude sites in unglaciated mountainous areas, where there was enough warmth and moisture to provide a suitable habitat. Geological evidence indicates that one of the areas sampled in this study, the Strandja Mountains, was left unglaciated during the last glaciation. Strandja's proximity to the Black Sea creates a mild, moist microclimate that today supports the only subtropical rainforest in Europe. This unique environment in Strandja was very likely one of the refugia for oaks during the Late Glacial period, and the area's forests preserve one of Europe's only pre-glacial relict populations.

The transition to moister and warmer climate conditions ca. 13,000 years ago provided an impulse for oaks to spread northwards from glacial refugia like Strandja. Pollen data indicate local expansion of Quercus into NW Romania by ca. 10,750 cal yr BP. Pollen and macrofossil data suggest that oak advanced to southern Poland by around 10-9.139 cal kyr BP (Goslar and Pazdur 1985; Milecka et al. 2004).

Quercus migration is much slower than that of many other genera, approximately 5-500 m/year (Lang 1994), because oak acorns cannot be dispersed over long distances by wind and are distributed mainly by jays and squirrels. It would have been difficult for heavy acorns to cross high mountains (which would have had largely unsuitable environmental conditions for oak), but sheltered mid-altitude mountain slopes would have provided favorable warm, moist environments for oak populations (Björkman et al. 2003).

The eastern and northeastern slopes of the Carpathians and their foreland contain large mid-altitude areas and deep incised river valleys that could have provided favorable shelter for migrating oak populations and a pathway through the Carpathians to NCE (Bodnariuc et al. 2002; Björkman et al. 2003; Tanţău et al. 2011). The same sheltered mid-altitude sites and valleys that provided oaks with a post-glacial colonization pathway from the Balkans to NCE also provide conditions that favor common tree-ring growth patterns that can be dendrochronologically crossdated (i.e. at the site of Sibiu, \#13).

\section{Dendrochronological Research Applications of the SE European Oak Network}

The SE European tree-ring network developed here links the networks of oak chronologies in NCE and the EM. With this proj- ect, we have delineated geographic areas with common patterns of year-to-year tree-ring variability, i.e. areas with the same "dendrochronological signal," over the past 200 years. The chronologies built for this project can now be gradually extended back in time with dendrochronologically dated timbers from historical, archaeological, and paleoenvironmental sites.

The extension of the chronologies presented here will allow us to determine if the borders of the delineated dendrochronological zones are consistent over time or shift in response to longterm changes in climate and environment. Future research will also identify the climate response patterns of site chronologies within our study area and investigate the impact of large-scale atmospheric circulation patterns on spatial and temporal variability in the tree-ring network. The development of these long oak chronologies for SE Europe will contribute additional tree-ring data for paleoclimatic research, building on previous dendroclimatic work with other species in the region (e.g. Popa and Kern 2008; Panayotov et al. 2010; Trouet et al. 2012).

A dense spatial network of long tree-ring chronologies is the key to bridging spatial and temporal gaps in the existing NCE and EM tree-ring records. The dense network of local chronologies will increase the effectiveness of dendrochronological dating of wood by providing new reference chronologies that capture a wider range of regional variability in the tree-ring record. This denser network also allows us to define the boundaries of distinct dendrochronological zones in Europe, which in turn improves the precision with which we can determine the provenance of wood used in buildings, ships, works of art, and other objects. Such improvements in dendroprovenancing for Europe and the Aegean will make it possible to reconstruct past patterns and intensities of timber trade, building on similar research efforts elsewhere in Europe (e.g. Haneca et al. 2005).

The results of this project are in effect an introductory chapter to a yet unwritten book on the history and paleoecology of SE Europe based on the area's tree-ring archives. There is only one serious obstacle: as we observed during fieldwork, potential sources of long tree-ring sequences - including old living trees and timber from historical/cultural heritage sites - are rapidly disappearing in the region, and without immediate action, the book on SE European tree rings will never be written. Consequently, the research efforts summarized here should be continued and intensified before these valuable resources are lost. Fortunately, archaeological research in this region continues, and efforts continue to unearth wooden material for writing the rest of the region's history in tree rings.

\section{ACKNOWLEDGMENTS}

This work was supported by funding from the National Geographic Society grant \#8739-10, the Malcolm H. Wiener Foundation, the Akkerman Fortress Project funded by the British Institute of Archaeology at Ankara, and individual patrons of the 
Aegean Dendrochronology Project. This project was made possible through collaboration with an international research consortium, which included Jeni Kamenova Vasileva and Krassimir Leshtakov (Sofia University); Nesibe Köse, Ünal Akkemik, and Tuncay Güner (Istanbul University); Yuri Boltryk and Severin Sagaydak (Institute of Archaeology, National Academy of Sciences of Ukraine); Ionel Popa and Constantin Nechita (Forest Research and Management Institute in Câmplung Moldovenesc, Romania); and Josef Kyncl and Tomaš Kyncl (DendroLab Brno, Czech Republic). We also thank Peter Brewer for creating the site maps, to our friends from the national parks in Shumen Plateau, Zlatni Piasci, and Strandja, and especially to Peter I. Kuniholm for inspiration and valuable comments. Furthermore, we would like to thank the anonymous reviewers for comments and important suggestions.

\section{REFERENCES}

Akkemik, Ü., N. Dağdeviren, and A. Aras, 2005. A preliminary reconstruction (AD 1635-2000) of spring precipitation using oak tree-rings in the western Black Sea region of Turkey. International Journal Biometeorology 49(5):297-302.

Baillie, M. G. L., 1982. Tree-Ring Dating and Archaeology. University of Chicago Press, Chicago.

Baillie, M. G. L., 1983. Is there a single British Isles oak tree-ring signal? In Proceedings of the 22nd Symposium on Archaeometry, April, 1982, edited by A. Aspinall, and S. E. Warren; pp. 73-82. University of Bradford, Bradford, UK.

Baillie, M. G. L., and J. R. Pilcher, 1973. A simple crossdating program for treering research. Tree-Ring Bulletin 33:7-14.

Bernabei, M., and J. Bontadi, 2012. Dendrochronological analysis of the timber structure of the Church of the Nativity in Bethlehem. Journal of Cultural Heritage 13(4) supplement:e54-e60.

Bielec-Bakowska, Z., 2010. A classification of deep cyclones over Poland (19712000). Physics and Chemistry of the Earth 35(9-12):491-497.

Bilyayeva, S., O. Fialko, A. Turner, and T. Ważny, 2010. Historical-archaeological investigations at Akkerman (Bilhorod-Dnistrovsky) fortress, Ukraine. Anatolian Archaeology 16:7-8.

Billamboz, A., 2003. Tree rings and wetland occupation in Southwest Germany between 2000 and 500 BC: Dendroarchaeology beyond dating in tribute to F. H. Schweingruber. Tree-Ring Research 59(1):37-49.

Björkman, L., A. Feurdean, and B. Wohlfarth, 2003. Late-Glacial and Holocene forest dynamics at Stereogoiu in the Gutaiului Mountains, Northwest Romania. Review of Palaeobotany and Palynology 124(1-2):79-111.

Bodnariuc, A., A. Bouchette, J. J. Dedoubat, T. Otto, M. Fontugne, and G. Jalut, 2002. Holocene vegetational history of the Apuseni mountains, central Romania. Quaternary Science Reviews 21(12-13):1465-1488.

Bojariu, R., and F. Giorgi, 2005. The North Atlantic Oscillation signal in a regional climate simulation for the European region. Tellus A 57(4):641-653.

Bonde, N., I. Tyers, and T. Ważny, 1997. Where does the timber come from? Dendrochronological evidence of timber trade in Northern Europe 14th to 17th century. In Archaeological Science 1995, edited by A. Sinclair, E. Slater, J. Gowlett; pp. 201-204. Oxbow Books, Oxford.

Brewer, S., R. Cheddadi, J. L. De Beaulieu, and M. Reille, 2002. The spread of deciduous Quercus throughout Europe since the last glacial period. Forest Ecology and Management 156(1-3):27-48.

Büntgen, U., W. Tegel, K. Nicolussi, M. McCormick, D. Frank, V. Trouet, J. O. Kaplan, F. Herzig, K. U. Heußner, H. Wanner, J. Luterbacher, and J. Esper, 2011. 2500 years of European climate variability and human susceptibility. Science 331(6017):578-582.

Cedro, A., 2007. Tree-ring chronologies of downy oak (Quercus pubescens), pedunculate oak $(Q$. robur $)$ and sessile oak $(Q$. petraea $)$ in the Bielinek Nature Reserve: Comparison of the climatic determinants of tree-ring width. Geochronometria 26:39-45.

Čufar, K., M. de Luis, M. Zupančič, and D. Eckstein, 2008. A 548-year long treering chronology of oak (Quercus spp.) for southeast Slovenia and its signif- icance as dating tool and climate archive. Tree-Ring Research 64(1):3-15.

Dering, M., A. Lewandowski, K. Ufnalski, and A. Kędzierska, 2008. How far to the east was the migration of white oaks from the Iberian refugium? Silva Fennica 42(3):327-335.

Ducousso, A., and S. Bordacs, 2004. EUFORGEN. Technical Guidelines for genetic conservation and use for pedunculate and sessile oaks (Quercus robur and Q. petraea). International Plant Genetic Resources Institute, Rome; 6 pp.

Eckstein, D., and J. Bauch, 1969. Beitrag zur Rationalisierung eines dendrochronologischen Verfahrens und zur Analyse seiner Aussagesicherheit. Forstwissenschaftliches Centralblatt 88(4):230-250.

Eckstein, D., and S. Wrobel, 2007. Dendrochronological proof of origin of historic timber - retrospect and perspectives. In Volume 5: Proceedings of the Symposium of Tree Rings in Archaeology, Climatology and Ecology, edited by K. Haneca, A. Verheyden, H. Beeckmann, H. Gärtner, G. Helle, G. Schleser, G. Tervuren; pp. 8-20. Schriften des Forschungszentrums Jülich, Umwelt/ Environment 74.

Eckstein, D., F. Schwab, and W. H. Zimmermann, 1979. Aufbau und Anwendung einer Jahrringchronologie im niedersächsischen Küstenraum. Probleme der Küstenforschung im südlichen Nordseegebiet 13:99-121.

Eckstein, D., T. Ważny, J. Bauch, and P. Klein, 1986. New evidence for the dendrochronological dating of Netherlandish paintings. Nature 320(6061):465-466.

Eggertson, O., and A. Babos, 2002. Dendrochronological dating in Maramureş with special emphases on objects from the Maramureş Museum in Sighetul Marmației, Romania. Tradiţii şi patrimoniu 2-3:40-49.

Friedrich, M., S. Remmele, B. Kromer, J. Hoffmann, M. Spurk, K. F. Kaiser, C. Orcel, and M. Kuppers, 2004. The 12,460-year Hohenheim oak and pine tree-ring chronology from central Europe-A unique annual record for radiocarbon calibration and paleoenvironmental reconstructions. Radiocarbon 46(3):1111-1122.

Goslar, T., and F. M. Pazdur, 1985. 'Czarny dąb’ z Lublinka - najstarszy dąb kopalny z terenu Polski. Wszechświat 86:203-204.

Griggs, C. B., A. T. De Gaetano, P. I. Kuniholm, and M. W. Newton, 2007. A regional reconstruction of May-June precipitation in the north Aegean from oak tree-rings, AD 1089-1989. International Journal of Climatology 27(8):10751089.

Griggs, C. B., P. I. Kuniholm, M. W. Newton, J. Watkins, and S. W. Manning, 2009. A 924-year regional oak tree-ring chronology for North-Central Turkey. In Tree-Rings, Kings, and Old World Archaeology and Environment: Papers Presented in Honor of Peter Ian Kuniholm, edited by S. W. Manning, and M. J. Bruce; pp. 71-80. Oxbow Books, Oxford.

Haneca, K., Ważny, T., Van Acker, J., and Beeckman, H., 2005. Provenancing Baltic timber from art historical objects: Success and limitations. Journal of Archaeological Science 32:261-271.

Haneca, K., K. Čufar, and H. Beeckman, 2009. Oaks, tree-rings and wooden cultural heritage: A review of the main characteristics and applications of oak dendrochronology in Europe. Journal of Archaeological Science 36(1):1-11.

Harris, K., A. Hamid, L. Madar, and P. Brewer, 2008. Corina User Guide. http:// dendro.cornell.edu/corina/corina.php.

Hillam, J., 1998. Dendrochronology. Guidelines on Producing and Interpreting Dendrochronological Dates. Ancient Monuments Laboratory, Conservation and Technology, English Heritage, London, 35 pp.

Hollstein, E., 1980. Mitteleuropäische Eichenchronologie. Trierer dendrochronologische Forschungen zur Archäologie und Kunstgeschichte. Trier Grabungen und Forschungen 11. Verlag Philipp von Zabern, Mainz am Rhein.

Holmes, R. L., 1983. Computer-assisted quality control in tree-ring dating and measurement. Tree-Ring Bulletin 43:69-78.

Hughes, M. K., P. I. Kuniholm, J. K. Eischeid, G. Garfin, C. B. Griggs, and C. Latini, 2001. Aegean tree-ring signature years explained. Tree-Ring Research 57(1):67-73.

Jansma, E., 1995. RemembeRINGs: The Development and Application of Local and Regional Tree-Ring Chronologies of Oak for the Purposes of Archaeological and Historicalal Research in the Netherlands. Ph.D. dissertation, Amsterdam University. Nederlandse Archeologische Rapporten 19. 149 pp.

Karaca, M., A. Deniz, and M. Tayanç, 2000. Cyclone track variability over Turkey in association with regional climate. International Journal of Climatology 20(10):1225-1236.

Kaznacheeva, V. D., and S. V. Shuvalov, 2012. Climatic characteristics of Mediterranean cyclones. Russian Meteorology and Hydrology 37(5):315-323. 
Kolar, T., T. Kyncl, and M. Rybniček, 2012. Oak chronology development in the Czech Republic and its teleconnection on a European scale. Dendrochronologia 30(3):243-248.

Krąpiec, M., 1998. Oak dendrochronology of the Neoholocene in Poland. Folia Quaternaria 69:5-133.

Kuniholm, P. I., 1996. Long tree-ring chronologies for the eastern Mediterranean. In Archaeometry 94: Proceedings of the 29th International Symposium on Archaeometry, Ankara 9-14 May 1994, edited by S. Demirci, A. M. Ozer, and G. D. Summers; pp. 401-409. Tubitak, Ankara, Turkey.

Kuniholm, P. I., 2000. Dendrochronologically dated Ottoman monuments. In $A$ Historical Archaeology of the Ottoman Empire: Breaking New Ground, edited by U. Baram, and L. Carroll; pp. 93-136. Plenum Press, New York.

Kuniholm, P. I., and C. L. Striker, 1987. Dendrochronological investigations in the Aegean and neighboring regions, 1983-1986. Journal of Field Archaeology 14(4):385-398.

Läänelaid, A., K. Sohar, and T. Meikar, 2008. Present state and chronology of oaks in an oak forest in Saaremaa Island, Estonia. Baltic Forestry 14(1):34-43.

Lang, G., 1994. Quartäre Vegetationsgeschichte Europas. Methoden und Ergebnisse. Gustav Fischer Verlag, Jena, Germany.

Lorentzen, B. E., 2014. Variability in Levantine Tree-Ring Records and Its Applications in Dendrochronological Dating, Provenancing, and Paleoenvironmental Reconstruction in the Southern Levant. Ph.D. dissertation, Cornell University, Ithaca, New York.

Medwecka-Kornaś, A., 1972. Czynniki naturalne wpływające na rozmieszczenie geograficzne roślin w Polsce. In Szata roślinna Polski, I, edited by W. Szafer, and K. Zarzycki; pp. 35-94. PWN, Warsaw.

Meiggs, R., 1982. Trees and Timber in the Ancient Mediterranean World. Clarendon Press, Oxford.

Milecka, K., M. Kupryjanowicz, M. Makohonienko, I. Okuniewska-Nowaczyk, and D. Nalepka, 2004. Isopollen history of trees and shrubs: Quercus L. Oak. In Late Glacial and Holocene History of Vegetation in Poland based on Isopollen Maps, edited by M. Ralska-Jasiewiczowa, M. Latałowa, K. Wasylikowa, K. Tobolski, E. Madeyska, H. E. Wright, and C. Turner; pp. 189-197. W. Szafer Institute of Botany, Polish Academy of Sciences, Kraków.

Müller, A., and Heußner K.-U., 2012. Dendro-provenancing extreme for Suakin Sudan. In TRACE - Tree Rings in Archaeology, Climatology and Ecology. Program and Abstracts of the Dendrosymposium 2012, May 9-12, 2012, Potsdam and Eberswalde, Germany; pp. 31.

Nechita, C., 2013. Reţeaua naţională de serii dendrocronologice pentru stejar și gorun. Ph.D. dissertation, University of Suceava, Romania.

Ozenda, P., 1994. La végétation du continent européen. Delachaux and Niestlé, Lausanne.

Panayotov, M., P. Bebi, V. Trouet, and S. Yurukov, 2010. Climate signal in treering chronologies of Pinus peuce and Pinus heldreichii from the Pirin Mountains in Bulgaria. Trees 24(3):479-490.

Pearson, C. L., C. B. Griggs, P. I. Kuniholm, P. W. Brewer, T. Ważny, and L. Canady, 2012. Dendroarchaeology of the mid-first millennium AD in Constantinople. Journal of Archaeological Science 39(11):3402-3414.

Petit, R. J., S. Brewer, S. Bordacs, K. Burg, R. Cheddadi, E. Coart, J. Cottrell, U.
M. Csaikl, B. C. van Dam, J. D. Deans, S. Fineschi, R. Finkeldey, I. Glaz, P. G. Goicoechea, J. S. Jensen, A. O. Konig, A. J. Lowe, S. F. Madsen, G. Matyas, R. C. Munro, F. Popescu, D. Slade, H. Tabbener, S. M. G. de Vries, B. Ziegenhagen, J.-L. de Beaulieu, and A. Kremer, 2002. Identification of refugia and post-glacial colonization routes of European white oaks based on chloroplast DNA and fossil pollen evidence. Forest Ecology and Management 156(1-3):49-74.

Pilcher, J. R., M. G. L. Baillie, B. Schmidt, and B. Becker, 1984. A 7272-year treering chronology for western Europe. Nature 312(5990):150-152.

Popa, I., and Z. Kern, 2008. Long-term summer temperature reconstruction inferred from tree-ring records from the Eastern Carpathians. Climate Dynamics 32(7-8):1107-1117.

Rinn, F., 2005. TSAP - Time Series Analysis and Presentation. Version 0.53 for Microsoft Windows - User Reference. Heidelberg, Germany.

Sander, C., and T. Levanič, 1996. Comparison of t-values calculated in different dendrochronological programmes. Dendrochronologia 14:269-272.

Schaub, M., K. F. Kaiser, D. C. Frank, U. Büntgen, B. Kromer, and S. Talamo, 2008. Environmental change during the Alleröd and Younger Dryas reconstructed from Swiss tree-ring data. Boreas 37(1):74-86.

Schweingruber, F. H., 1988: Tree Rings: Basics and Application of Dendrochronology. D. Reidel Publishing, Dordrecht, the Netherlands.

Schweingruber, F. H., and U. Ruoff, 1979. Stand und Anwendung der Dendrochronologie in der Schweiz. Zur dendrochronologischen Datierung älterer Holzbauten in der Schweiz. Zeitschrift für Schweizerische Archäologie und Kunstgeschichte 36(2):69-90.

Sohar, K., A. Läänelaid, D. Eckstein, S. Helama, and J. Jaagus, 2014. Dendroclimatic signals of pedunculate oak (Quercus robur L.) in Estonia. European Journal of Forest Research 133(3):535-549.

Tantău, I., A. Feurdean, J. L. de Beaulieu, M. Reille, and S. Fărcaş, 2011. Holocene vegetation history in the upper forest belt of the Eastern Romanian Carpathians. Palaeogeography, Palaeoclimatology, Palaeoecology 309(34):281-290

Trouet, V., M. Panayotov, A. Ivanova, and D. Frank, 2012. A pan-European summer teleconnection mode recorded by a new temperature reconstruction from the northeastern Mediterranean (AD 1768-2008). The Holocene 22(8):887898.

Tyers, I., 2004. Dendro for Windows program guide. ARCUS Rep. 340.

Ufnalski, K., 2006. Teleconnection of 23 modern chronologies of Quercus robur and $Q$. petraea from Poland. Dendrobiology 55:51-56.

Ważny, T., 1990. Aufbau und Anwendung der Dendrochronologie für Eichenholz in Polen. Ph.D. dissertation, University of Hamburg.

Ważny, T., 2009. Is there a separate tree-ring pattern for the Mediterranean oaks? In Tree-Rings, Kings, and Old World Archaeology and Environment: Papers Presented in Honor of Peter Ian Kuniholm, edited by Manning, S. W., and M. J. Bruce; pp. 41-50. Oxbow Books, Oxford.

Ważny, T., and D. Eckstein, 1991. The dendrochronological signal of oak (Quercus spp.) in Poland. Dendrochronologia 9:35-49.

Wigley, T. M. L., P. D. Jones, and K. R. Briffa, 1987. Cross-dating methods in dendrochronology. Journal of Archaeological Science 14(1):51-64. 